\title{
JOB QUALITY AND WELL-BEING IN OECD COUNTRIES
}

\author{
Xose PICATOSTE (D)1, Mirela Ionela ACELEANU (D)2, \\ Andreea Claudia ȘERBAN (iD $3^{*}$ \\ ${ }^{1}$ Economic Development and Social Sustainability Research Group (EDaSS), Department of Economics, \\ Faculty of Economics and Business, Universidade da Coruna, A Coruña 15071, Spain \\ 2, 3 Department of Economics and Economic Policy, Faculty of Theoretical and Applied Economics, \\ Bucharest University of Economic Studies, Romana Square, No. 6, 010374 Bucharest, Romania
}

Received 18 May 2020; accepted 11 January 2021

\begin{abstract}
The lifestyle of world citizens has suffered an unprecedented impact as a result of the health crisis caused by the COVID-19. Economies and worldwide societies expect huge damages comparable to that caused by war. To the effects of this crisis on employment and wages must be added those produced in the workplace, with a foreseeable increase in job strain, not only as of the result of the health security reasons in the workplace but also to the effects on work-life balance, training and promotion possibilities, etc. This research analyses the impact of the economic situation on health, the influence of health on labour strain and on job quality. Using OECD data and a structural equation model, we have investigated the relationship between economy, health, quality of the job, work-life balance and well-being. The importance of security and safeness in the workplace is one of the items for evaluating job strain, particularly when they become even more crucial in pandemic times. This issue implicates not only the real risk of individual and social health but also a stressful situation for workers. The main contribution of our paper relies on establishing and prove causal relations among social and economic variables related to health, well-being and job quality, including safeness at the workplace. Considering that this relationship will probably become reinforced after a pandemic, like COVID-19, the actual relevance of the analysed topic and the achieved results becomes crucial.
\end{abstract}

Keywords: labour strain, job quality, healthcare, well-being, work-life balance, COVID-19.

JEL Classification: J01, J08, J28, J81, I15, I31.

\section{Introduction}

Advanced societies have made a long way to improve labour conditions, job environment as well as life-work balance. Recently, an unexpected health shock has drawn uncertain situations where not only earnings but also security become at the centre of the labour market debate.

*Corresponding author. E-mail: andreea.serban@economie.ase.ro

Copyright (c) 2021 The Author(s). Published by Vilnius Gediminas Technical University

This is an Open Access article distributed under the terms of the Creative Commons Attribution License (http://creativecommons. org/licenses/by/4.0/), which permits unrestricted use, distribution, and reproduction in any medium, provided the original author and source are credited. 
Some countries, Spain heading them, have faced the challenge of disease without providing the proper protection to workers in their job environment. As a result, they got one of the highest numbers of sanitary workers infected by the COVID-19 worldwide. The adaptive component in healthcare systems is increasingly needed to improve their current keys dilemmas: depth versus breadth, selection versus configuration, and accuracy versus transparency (Spruit \& Lytras, 2018; Alsaywid et al., 2020). The fright to the disease and the unsafeness in the work environment took place at the same time that a lot of people were losing their jobs and were becoming economically and socially vulnerable. Now is the time that the social and healthcare policies claim their core role in this situation, precisely when the weakness of the economy is increasing, and the debate about which is the most urgent spend to face has to be faced is on the core of the political agenda. Analysing the effects of job strain on people's lives is the primary goal of this paper. The value of the results achieved relies on demonstrating the causal connection between health and the labour market in general as well as specific areas of work, like job strain. Considering that this relationship will probably become reinforced after a pandemic, like COVID-19, the actual relevance of the analysed topic and the achieved results becomes crucial.

The researchers and international organisations have already conducted researches on COVID-19, referring to the impact on the economy, health systems, business environment. Health systems have been severely influenced but more affected will be the economy, which requires recovery measures during and after COVID-19 (Chesbrough, 2020; United Nations Statistics Division [UNSD], 2020). An essential role in recovery has innovation. Joining forces, both in the medical field (through international collaboration to find a vaccine and to identify the most appropriate treatments) and in the industry (by expanding the production of necessary medical products, such as ventilators) is the starting point in overcoming the effects of COVID-19, in recovering the deteriorated well-being and in recalibrating the job quality considering the new existing conditions.

The opening to collaboration and new approaches will speed the internal innovation process, and allow everybody to take advantage of the knowledge of others in their business.

The objective of the article is to analyse the critical factors for influencing the job strain and workers' quality of life. Using a multi-dimensional framework, we have investigated the relationship between economy, health, quality of the job, work-life balance and well-being. The importance of security and safeness in the workplace is one of the items for evaluating job strain, particularly when they become even more crucial in pandemic times. Right now, this issue implicates not only the real risk of individual and social health but also a stressful situation for workers. The main contribution of our paper relies on establishing and prove causal relations among social and economic variables related to health, well-being and job quality, including safeness at the workplace.

The rest of the paper is organised as follow. The next section comprises the literature review, Section 2 describes the methodology and data used, Section 3 provides analysis and findings, and the last section points out concluding remarks. 


\section{Theoretical framework}

High strain jobs have adverse consequences for health and work participation and consequently on the job quality and well-being. Integrating job strain into well-being research becomes of major importance in the current societies, considering the rapid changes characterising the labour market (changing of the occupational structure as a result of increasing incorporation of knowledge) as well as the occurrence of recessions or other crisis as there are the new challenges associated with health status that will impose new dimensions of job strain in the near future (Bliese et al., 2017). It makes sense to expect that in the postpandemic times, citizens claim for this reinforcement on health security after COVID-19.

The job quality represents a variable that should be considered for a better understanding of the measures of an economy and the interrelations between economies and societies. Considering only GDP (which is a measure of market production) and other socially-oriented measures (e.g. poverty, unemployment rate, real wages etc.) will result in an inadequate and incomplete assessment of a healthy economy. Job quality is a multi-dimensional concept, and it could include a variety of dimensions (Warhurst et al., 2017). The term refers to many aspects, focusing on employee (from this point of view it refers to the extent to which the job attributes influence the workers' well-being, the worker being the best positioned to evaluate how the job affects the well-being) (Muñoz de Bustillo et al., 2011), on employers (fair work and profits), on the worksite (the quality of working life) or the economy as a whole. As a result, within the job quality term, the quality of employment and quality of work could be analysed separately. United Nations defines seven dimensions of job quality: safety and ethics; income and benefits; working time and work-life balance; security of employment and social protection; social dialogue; skills development and training; employment-related relationships and work motivation (United Nations, 2015). Referring to the quality of work some studies identify the following five dimensions: ergonomic, autonomy, control, complexity, economic dimensions (Centra \& Gualtieri, 2014).

Also, even job quality has a subjective dimension (preferences of the workers) and an objective dimension as well (the characteristics of the job, such as pay), the aim is to evaluate job quality independent of workers' personal preferences or circumstances. For considering both subjective understandings and objective circumstances, the job quality should be understood in the context of an individual situation, labour market characteristics and social-economic context (Goods et al., 2019). Some authors restrict the job quality to aspects related to one variable: wages, considering that policies aimed at improving earnings equality are essential to reduce workers' poverty (Osterman \& Shulman, 2011). Other authors take into account three dimensions: earnings quality; labour market security; and quality of the working environment (OECD, 2016). In the literature, there are many variables describing job quality concept. The most often used are wages; health and well-being; work-life balance; conductive environment; job security correlated with training opportunities, prospect, promotion, personal accomplishment; work effort (de la Poza et al., 2020; OECD, 2013; Green, 2006; Kalleberg, 2011; Muñoz de Bustillo et al., 2011; Hauff \& Kirchner, 2014; Warhurst et al., 2017).

Strain jobs are those where job demands are higher than resources at workers disposal. Job demands refer to time pressure (high work intensity, long working hours and working 
time inflexibility) and physical health risk factors (viruses like the new COVID-19, dangerous or hard work). Job resources refer to opportunities to learn, work autonomy, support from the working team (OECD, 2014). In order to have a positive impact within job resources, the main emphasis in the learning process should be paid to the management of personal profiles and identities, to the specific situations and learning objects (Elci \& Uzunboylu, 2020; Vargas-Vera \& Lytras, 2008; Sicilia \& Lytras, 2005).

The well-being of workers is influenced by the quality of the working environment, the organisational-level initiatives being able to promote employee well-being (Moen et al., 2016). Models developed to identify attributes that affect workers' health pointed at jobs demands which require physical, cognitive and emotional effort (e.g. time pressure, heavy workload, conflicting demands, etc.) and job resources which can be physical, organisational or social. Low/insufficient job resources imply difficulties in achieving work goals, coping with challenging demands or exciting personal development. Finally, excessive demands and inadequate resources lead to job strain. Even job demands are creative, proactive or positive they can turn into job stressors if the workers' job resources do not meet the job demands (Cazes et al., 2015; OECD, 2014). Moreover, under conditions of job strain, work engagement is less likely to translate into high proactivity with effects of production, both qualitatively and quantitatively (Schmitt et al., 2016).

Studies showed that gender and education, the irregular working hours and spaces, the job position influence job strain. Jobs could be classified as low-strain and high-strain to explore prognostic factors. Under these circumstances, high-strain jobs were associated with gender (female), education (lower), shift work or doing work outside the workplace (Warren \& Lyonette, 2018; Clark, 2005). Low-strain jobs were associated with the same variables and opposite values and, besides, with lower job position (Bonsaksen et al., 2019). Also, the existence of trade unions protects against downward movements in job quality (Clark, 2005).

Job strain is also associated with temporary employment as a result of the workers' peripheral position in the labour market and the fulfilment of work-tasks whilst often looking for a permanent job (Inanc, 2018). From the lack of opportunities for organisational participation perspective, the temporary employment is associated with low psychological well-being (Inanc et al., 2015; Hall, 2006). Other studies show that the job strain is lower for self-employed individuals and within this category, the job strain is higher for those with employees as a result of higher job demand (Hessels et al., 2017).

The individual well-being of workers can be influenced through the channel of labour market insecurity (Vander Elst et al., 2016). Even there is stressed a potentially positive outcome of job loss, e.g. increased career adaptability and the quality of reemployment expressed by higher initial wages and longer employment periods (Simion \& Warner, 1992; Zikic \& Klehe, 2006); the recent studies show that higher unemployment rates increase job strain for employed workers as well as the emotional and financial involvement with those who lose their jobs (Hijzen \& Menyher, 2016; Jurevičienè et al., 2020).

The well-being is related to work in two ways: well-being from work and well-being in work. The first refers mainly at the effects of unemployment on individual psychology (self-esteem for example) while the second relates to the impact of changes to work, being associated to satisfaction with self-realisation (Muñoz de Bustillo et al., 2011), productivity 
in the workplace and also with economic growth (Ozturk et al., 2019; Warhurst et al., 2017). Self-determination theory is used in correlation to the workplace to explain the increased high performance, autonomous motivation and well-being (Deci et al., 2017). From the point of view of the employer, it is presumed that market orientation culture improve firm performance through employee job satisfaction and product quality (Eberegbe \& Giovanis, 2020; Zhou et al., 2008).

The relation between the decline of job satisfaction and the rising of real wages is explained based on factors such as work intensification and its effects of work-life balance (Davoine et al., 2008). Work-life balance refers to time, involvement and satisfaction ratio and it was shown that individual who invest more time on family than work experienced a higher quality of life compared to balanced individuals, with overall effects on job involvement (Greenhaus et al., 2003). To take account of recent developments in today's societies, some authors proposed a new conceptualisation of work (new forms of working arrangements and relationships) and life (extending from childcare responsibilities to activities like education, religious, different hobbies or community activities) (Kelliher et al., 2019). Currently, companies need to focus on work-life balance issues, using flexible schedules and programs based on altruistic or social values which are likely to be more successful as in the past (Twerge, 2010). The work-life practices influence organisation performance in terms of cost savings or better productivity, but it is moderated by factors like job level, managerial support and macroeconomic context (Beauregard \& Henry, 2009). Influencing labour productivity is of major importance, considering it is a fundamental mechanism for transferring the economic growth to well-being through the channel of wages and incomes (International Labour Organization [ILO], 2013).

Much more, some authors consider that even if in today's industries the automation computers, robots and other digital technologies - may prevent the firms from creating new jobs, the focus is moving on the job quality in the detriment of the number of jobs (Autor, 2015). The empirical data shows that there is no trade-off between job creation and quality of jobs, considering the experience of the Northern countries with both higher rates of employment and higher job quality. Under these circumstances, job quality should be a specific target for national economies and it was recognised in this way by the Europe 2020 Strategy that aims to create more and better jobs for all in EU (European Commission , 2010; Erhel \& Guergoat-Larivière, 2016). Current changes in employment and work affect the job quality and intervention is needed to improve or maintain it. The major challenge is to identify what can be done, by whom, to predict the effects and to accurate point out the jobs that need changes, which are obsolete and to find the best solution for improvement (Findlay et al., 2017).

The COVID-19 pandemic represents a new challenge, and it is already a shock for economies and labour markets, affecting both supply and demand (Saladino et al., 2020). Not only the quantity of employment (increased unemployment and underemployment) but also the quality of jobs is deteriorating very rapidly as the negative impact spread to the global economy (Biddle, 2020). In terms of job quality, wages already decrease. Also, the effect is disproportionate, specific groups already vulnerable being most affected (older people, those with health problems, young persons, women - as they are in hired in the most affected sectors, 
self-employed or migrants) (ILO, 2020). To not negatively affect the well-being of workers, many countries have already adapted their social assistance programs in different ways, and they try not to deteriorate the access to social protection (Luecke \& Knabe, 2020; Gentilini et al., 2020). Employment protection and allowing working arrangements more flexible than ever are aimed to reduce job strain as a result of health security reasons (UNICEF, ILO, UN Women, 2020).

\section{Methodology and data used}

\subsection{Research model and hypotheses}

This paper deals with the importance of health as a critical matter which affects job strain and the influence on the workers' quality of life. An empirical analysis is performed in the context of developed countries. The main reason for selecting these countries is that they provide data about the quality of work as well as different factors determining it. As it was previously pointed out, the deterioration of labour market under the post-pandemic conditions will not only affect earnings and employment-rate but also to the precariousness of job conditions.

The main variables involved in this analysis are not readily observable in a direct way. We constructed them through some recognisable indicators, employing factorial analysis. A linear regression econometric technique is the one selected for proving the causal relationships. Both methods together are compiled by the structural equation analysis (SEM), the chosen one for this research. This method is the most suitable and widely recognised in social sciences for constructing some variables, which cannot be directly observable or measured employing some specific, measurable indicators related to them. Additionally, this method gives the possibility of testing casual relations among the latent or unobservable variables using linear regression analysis (Fornell \& Larcker, 1981).

According to economic literature, we deal with a theoretical model, establishing the connections and causal relationships among the economy, health, job strain, quality of the job and work-life balance as well as well being.

The assumptions are that after COVID-19 crisis, two main scenarios will appear. Firstly, people will give more importance to the healthcare system than other issues. Secondly, the job strain or quality of the environment of the job will become a vital issue (that is to say, the conditions of the place where the job is done, safety, security, work-life balance, training, flexibility, etc.). Its importance under the view of the workers and employers will probably increase.

The question to answer is if is there any relationship between these variables. If so, it will likely increase in the future.

The proposed simple scheme of the model is in Figure 1.

Taking into account the previous questions and the advancements in the academic literature, this work tries to verify if there are causal relationships between the situation in the workplace, economical and healthy environment, which explain the influence of job strain on quality life and well-being. Establishing some hypothesis to be tested will help to this goal. 


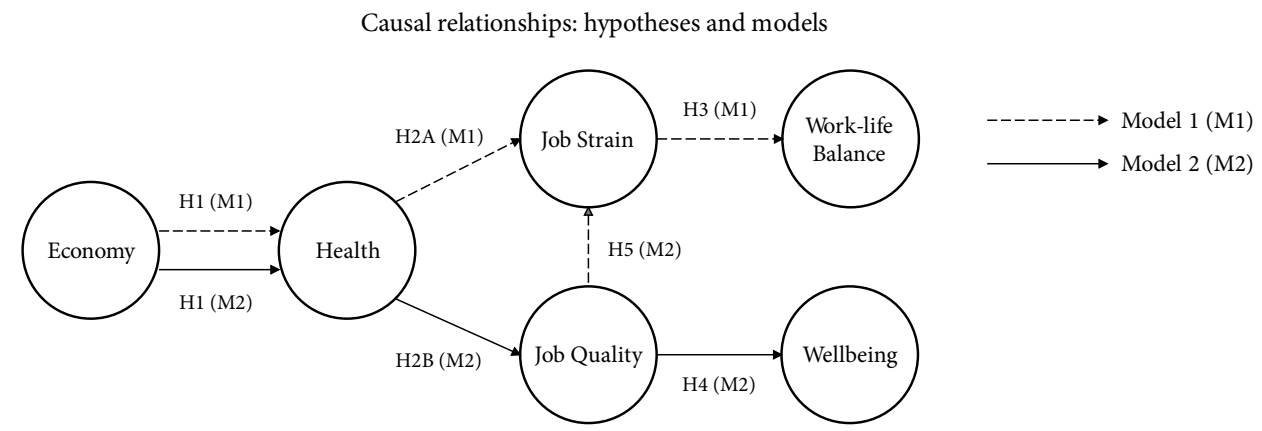

Figure 1. Primary relationships analysed among Economy, Health, Job Strain, Job Quality Work-life Balance and Wellbeing (source: authors' elaboration)

Hypotheses to be tested:

H1: Relationship between people's economic situation and health Null hypothesis (H1-0): Economic status does no influences health status;

$\mathrm{H} 2$ : Relationship between health and labour market and job conditions Null hypothesis (H2A-0): Health status does not influence job strain, Null hypothesis (H2B-0): Health status does not influence the quality of the job;

H3: Relationship between the job strain and the work-life balance

Null hypothesis (H3-0): The job strain does not influence the work-life balance;

H4: Relationship between the quality of the job and the well-being

Null hypothesis (H4-0): The quality of the job does not influence the well-being.

We have proposed two models to test these hypotheses. Both start from the influence of the economic situation on the health of the population and differ in the variables on which health influences: while the former focuses on the "job strain" to explain the "worklife balance" (Goods et al., 2019), the second is more complex and ambitious, introducing the concept of "Job Quality" (broader than "job strain", the fact "job strain" is explained by "job quality" - see section “A. Previous step: details about the Job Quality Index", where this relationship is explained and assessed), whose breadth and complexity allows explain the more general concept of "well-being" (Vander Elst et al., 2016; Simion \& Warner, 1992; Zikick \& Klehe, 2006).

Thus, we were able to have a broader vision of the combined effects of health and economics on the population (Warhurst et al., 2017; Deci et al., 2017; Zhou et al., 2008; Gentilini et al., 2020).

\subsection{Descriptive statistics}

The OECD context is the empirical framework for this research. We use data from the OECD job quality index statistics for 2005, 2010 and 2015 and other OECD indicators (updated to the last available data) described below. 
The OECD Job Quality Index is composed by three main areas, according to OECD:

1. Earnings quality. This area refers both to the level and the distribution of earnings across the workforce and it is a parameter referred as the coefficient of inequality aversion. Lower values correspond to higher inequality aversion and further to lower warnings quality.

2. Labour market insecurity. This area refers also to earnings, but in terms of expected loss associated with the risk of unemployment. The loss level depends on duration of unemployment and the generosity of government transfers for unemployed persons.

3. Quality of the working environment. This last area of Job Quality Index refers to the incidence of job strain among workers.

The summary of the three components of the Job Quality Index are shown in Table 1.

The job strain index is related to the quality of the working environment, and it is, as shown above, one of the three components of the Job Quality Index. The elements of job quality that influence job strain are reflected on Table 1, considering two different kinds of indicators: one related to the high level of job demands and the other to the low level of job resources.

Fist type of indicators refers to the high exigency of the job (high job demands) and is influenced mainly by three factors:

1. Physical health risk factors. This indicator informs about the risky environmental situations at the workplace (personal evaluation of workplace as dangerous or the existence of potential factors affecting workers' health: extreme temperature, high noise, exposed to chemicals, the occurrence of work accidents).

2. Long working hours. This indicator informs about the high number of hours spent at the workplace (more than 50 hours per week are considered too high).

3. Inflexibility of working hours. This indicator informs about the possibility of workers to take time off the job.

Table 1. Job Quality Components (OECD) (source: authors own elaboration based on OECD, 2020a, 2020b)

\begin{tabular}{|c|c|c|c|}
\hline \multicolumn{4}{|c|}{ Job Quality Components (OECD) } \\
\hline Overall measure & & & Components (units) \\
\hline $\begin{array}{l}\text { 1. Earnings } \\
\text { quality }\end{array}$ & \multicolumn{3}{|c|}{$\begin{array}{l}\text { Level and the distribution of earnings (constant prices, } \\
\text { at constant PPPs - \$ USA) }\end{array}$} \\
\hline $\begin{array}{l}\text { 2. Labour market } \\
\text { insecurity }\end{array}$ & \multicolumn{3}{|c|}{$\begin{array}{l}\text { Risk of becoming unemployed, expected time of unemployment and } \\
\text { government transfers for the mitigation against the unemployment (Percentage) }\end{array}$} \\
\hline \multirow{7}{*}{$\begin{array}{l}\text { 3. Quality of } \\
\text { the working } \\
\text { environment } \\
\text { (Job Strain) }\end{array}$} & & Job Strain \\
\hline & & & Physical health risk factors (Percentage) \\
\hline & & & Long working hours \\
\hline & & & The inflexibility of working hours (Percentage) \\
\hline & Job Strain & \multirow{3}{*}{$\begin{array}{l}\text { Low level of } \\
\text { job resources }\end{array}$} & $\begin{array}{l}\text { Work autonomy and learning opportunities } \\
\text { (Percentage) }\end{array}$ \\
\hline & & & Training and learning \\
\hline & & & Opportunity for career advancement (Percentage) \\
\hline
\end{tabular}


The second type of indicators refers to a low level of job resources:

1. Work autonomy and learning opportunities. Work autonomy refers to the way workers carry out their work activities, the possibility to choose the order of tasks and to adapt the methods of work. Learning opportunities refer both to formal education or training (provided by employer) and informal learning at work.

2. Training and learning refer to the number of employees that reported receiving training.

3. Opportunity for career advancement refers to the possibilities of promotion.

The relevant variables are not easily observed with a single indicator and, then, they need to be constructed utilising several observable variables. In consequence, they are the so-called "latent variables", composite or created from other observed indicators. The adequacy of the method is confirmed because it is the most suitable to explain casual relations among latent variables, which is precisely the primary goal of this paper.

Our model's main variables are the economy status of workers (the earnings and disposable income are fundamental indicators), the health status (some useful data could be the life expectance and the self-perceived health). The data of the observable variables for constructing the latent ones come from the OECD statistics database. All these variables are not directly observable. The factorial analysis and SEM were applied for constructing those latent variables and for testing the causal relationships, according to the hypotheses proposed below.

The sign of the relationships, according to literature for the hypotheses that must be tested, are reflected in Table 3.

Table 2. Quality of the working environment. Components (OECD) and the sign of the measurement for the indicator (source: authors own elaboration based on OECD, 2020a, 2020b)

\begin{tabular}{|l|l|c|}
\hline \multicolumn{2}{|c|}{ Expected relations among the indicators and the job strain } \\
\hline $\begin{array}{l}\text { High level of job demands } \\
\text { (positive relation to Job } \\
\text { Strain is expected) }\end{array}$ & Physical health risk factors & Positive \\
\cline { 2 - 3 } & Long working hours & Positive \\
\cline { 2 - 3 } & The inflexibility of working hours & Positive \\
\hline $\begin{array}{l}\text { Low level of job resources } \\
\text { (negative relation to Job } \\
\text { Strain is expected) }\end{array}$ & Work autonomy and learning opportunities & Negative \\
\cline { 2 - 3 } & Training and learning & Negative \\
\cline { 2 - 3 } & Opportunity for career advancement & Negative \\
\hline
\end{tabular}

Table 3. Relationships among latent variable and expected signs (source: authors' elaboration)

\begin{tabular}{|c|l|l|c|}
\hline Hypotheses & Explicative variable & Explained variable & Expected sign according to literature \\
\hline H1 & Economy & Health & Positive \\
\hline H2-A & Health & Job strain & Negative \\
\hline H2-B & Health & Quality of the job & Positive \\
\hline H3 & Job strain & Work-life balance & Negative \\
\hline H4 & Quality of the job & Well-being & Positive \\
\hline
\end{tabular}


In Table 4, there are shown the latent variables as well as their indicators. The next paragraph explains the description of the analytical relationship. To get the most updated data, the year 2017 was selected, except for the Job Quality.

The observable variables for each of the constructs or latent variables are as follows. Firstly, we would like to report about the transformation of some indicators to give consistence to the constructs and facilitate the interpretation or sings of the results. Table 2 (and also Table 1) shows the six components defining the job strain (or the quality of the environment at the job). Still, the first three of them are representing positive matters, while the last three represent negative characteristics. For the adequate measurement of the latent variable (the quality of the working environment) from the inhomogeneous measures of its indicators, some adjustments will be required.

The economy variable tries to assess the economic status of people, employing net income households and the earnings from jobs, the data for its three indicators were the financial wealth and the adjusted disposable income, and the personal earnings from jobs. With the aim of capturing the value of the comprehensive health status (without specifying diseases or sickness), some general indicators were selected. Three observable data construct the health variable. They are the life expectancy, life satisfaction and self-reported health.

Job strain was measured through the three values provided for the years 2005, 2010 and 2015 for each country and the Job Quality Index was gotten from the OECD data for its components (the job strain plus the quality of earnings and the insecurity in the labour market). The mean value for the years 2005-2016 was the selected indicator. Moreover, a

Table 4. Latent variables and their indicators (for all models) (source: authors' elaboration)

\begin{tabular}{|c|c|c|}
\hline \multicolumn{2}{|c|}{ Latent variables } & Observable variables \\
\hline \multirow{5}{*}{ Job Quality Index } & \multirow{3}{*}{$\begin{array}{l}\text { Quality of Environment at } \\
\text { Work (Job Strain) }\end{array}$} & Strain index 2005 \\
\hline & & Strain index 2010 \\
\hline & & Strain index 2015 \\
\hline & & Quality of Earnings \\
\hline & & Labour market security \\
\hline \multirow{2}{*}{ Work-Life Balance } & & No Working very long hours \\
\hline & & Leisure \& care \\
\hline \multirow{4}{*}{ Well-being } & & Water \\
\hline & & Safety \\
\hline & & Education score \\
\hline & & Leisure \& care \\
\hline \multirow{3}{*}{ Economy } & & Financial wealth \\
\hline & & Disposable income \\
\hline & & Personal earnings \\
\hline \multirow{3}{*}{ Health } & & Life expectancy \\
\hline & & Life satisfaction \\
\hline & & Self-reported health \\
\hline
\end{tabular}


transformation for the data of insecurity in the labour market was needed, in order to get the positive value of "security" measure instead of the negative of "insecurity". Regarding the work-life balance, two observable variables were selected, the time devoted to leisure and personal care and the transformed value (the same that for the insecurity into security). From the OCDE raw data for employees working long hours, a transformation was applied to get the indicator of "no long hours worked", and then, getting the construction of a latent variable with two indicators measuring on the same direction. The variable well-being is constructed through one indicator of environment quality (the water quality), other about safety (going home alone at night), other about education (the achieved scores) and one related to worklife balance (the time of leisure and self-care).

All data came from the OECD statistics and have been downloaded for the last available period. The job strain index was available for 2005, 2010 and 2015. The countries which provided full data and those with some lacks easily to estimate were selected. These countries are Australia, Austria, Belgium, Canada, Chile, Czech Republic, Denmark, Estonia, Finland, France, Germany, Hungary, Iceland, Ireland, Israel, Italy, Japan, Korea, Latvia, Luxembourg, Mexico, Netherlands, New Zealand, Norway, Poland, Portugal, Slovak Republic, Slovenia, Spain, Sweden, Turkey, the United Kingdom and the United States.

\subsection{Structural Equation Modelling (SEM)}

\subsubsection{SEM approach}

Structural Equations is the most suitable method since it allows the use of latent variables (not directly observed), but that can be constructed using the corresponding indicators. The SEM models (Structural Equation Models) have been useful to face many substantive problems in the social and behavioural sciences, as well as multiple social sciences areas, like economics, marketing, sociology, psychology, education and econometrics (Jöreskog \& Sörbom, 1982). This method comes from the models based on the "path analysis" proposed by Wright $(1934,1960)$ and later developed by Jöreskog (1973) and by Jöreskog and Sörbom (1982). SEM models mostly consist of analysing the causality between one or several variables (independent/or dependent), taking into account the existence of multiple interrelationships between them, which introduces causality. It is possible working simultaneously with observed and latent variables, but it is worth highlighting the potential of the proposed methodology for the study of causal relationships between unobservable variables. The aim is to jointly apply the techniques of factor analysis and linear regression, within a theoretical frame of reference. This method allows the "creation" or "building" those variables that cannot be directly observed, mainly due to the multiplicity of factors that make them up (e.g. "work-life balance" or "well-being"), these are the so-called "latent variables or construct". This method has been widely applied to the analysis of health, job quality (Rusli et al., 2008) as well as well-being (Novo-Corti et al., 2017).

\subsubsection{Applying SEM in job quality analysis}

With the aim of testing all the hypotheses and the stated causal relationships proposed (see Figure 1), a two steps procedure was selected. Firstly, we constructed the index of job quality with the method of SEM to prove the significance of all components. Secondly, we show 
a model (Model 1) test the explanation of Job Strain and Work-life balance and another more complex model (Model 2) to test the hypothesis 3 and 4 about the job quality index and the well-being. The solution for the test for all hypothesis is provided after the analysis of both models. A graphical summary of relationships jointly with the hypotheses is shown in Figure 1.

To summarise, the construction of the unobservable variables for the Model 2 (the most complete one) are given by the following measurement model equations are:

For the latent variable Economy $\left(\xi_{1}\right)$ :

$$
\begin{aligned}
& x_{1}=\lambda_{11}^{x} \xi_{1}+\delta_{1} ; \\
& x_{2}=\lambda_{21}^{x} \xi_{1}+\delta_{2} ; \\
& x_{3}=\lambda_{31}^{x} \xi_{1}+\delta_{3},
\end{aligned}
$$

where: $x_{1}$-Finanacial wealth ; $x_{2}$-Disposable income ; $x_{3}$-Personal earnings.

For the latent variable Health $\left(\eta_{1}\right)$ :

$$
\begin{aligned}
& y_{11}=\lambda_{11}^{y} \eta_{1}+\varepsilon_{1} ; \\
& y_{12}=\lambda_{21}^{y} \eta_{1}+\varepsilon_{2} ; \\
& y_{13}=\lambda_{31}^{y} \eta_{1}+\varepsilon_{3},
\end{aligned}
$$

where: $\eta_{1}$ - Health status; $y_{11}$ - Life expectancy; $y_{12}$ - Life satisfaction; $X y_{13}$-Self - reported health.

For the latent Job Quality Index $\left(\eta_{2}\right)$ :

$$
\begin{aligned}
& y_{12}=\lambda_{13}^{y} \eta_{2}+\varepsilon_{4} ; \\
& y_{22}=\lambda_{23}^{y} \eta_{2}+\varepsilon_{5} ; \\
& \eta_{3}=\gamma_{32} \eta_{2}+\zeta_{3},
\end{aligned}
$$

where: $\eta_{2}$ - Job Quality Index; $y_{12}$-Quality of earnings; $y_{23}$-Sequrity of job environment.

For the latent Job Strain $\left(\eta_{3}\right)$ :

$$
\begin{aligned}
& y_{13}=\lambda_{13}^{y} \eta_{3}+\varepsilon_{6} ; \\
& y_{23}=\lambda_{23}^{y} \eta_{3}+\varepsilon_{7} ; \\
& y_{33}=\lambda_{33}^{y} \eta_{3}+\varepsilon_{8},
\end{aligned}
$$

where: $\eta_{3}$ - Job Strain; $y_{13}$ - Job Strain Index (2005); $y_{23}$ - Job Strain Index (2010); $y_{33}$ - Job Strain Index (2015).

For the latent Well-being $\left(\eta_{4}\right)$ :

$$
\begin{aligned}
& y_{14}=\lambda_{14}^{y} \eta_{4}+\varepsilon_{9} ; \\
& y_{24}=\lambda_{24}^{y} \eta_{4}+\varepsilon_{10} ; \\
& y_{34}=\lambda_{34}^{y} \eta_{4}+\varepsilon_{11} ; \\
& y_{44}=\lambda_{44}^{y} \eta_{4}+\varepsilon_{12},
\end{aligned}
$$

where: $\eta_{4}$ - Well - being; $y_{14}$-Envionment(Clean water); $y_{24}$-Safety; $y_{34}$-Education; $y_{34}$ - Work - life balance(leisure time). 
The values of $\delta$ and $\varepsilon$ are those correspondents to the measurement errors, while the $\zeta$ are the estimation errors.

Regarding the causal relationships, the correspondent equations are:

$$
\begin{aligned}
& \eta_{1}=\beta_{21} \xi_{1}+\zeta_{1} ; \\
& \eta_{2}=\beta_{21} \eta_{1}+\zeta_{2} ; \\
& \eta_{3}=\beta_{32} \eta_{2}+\zeta_{3} ; \\
& \eta_{4}=\beta_{43} \eta_{3}+\zeta_{4} .
\end{aligned}
$$

Summarising:

$$
\begin{aligned}
& \eta_{4}=\beta_{32}\left(\beta_{32}\left(\beta_{21}\left(\beta_{21} \xi_{1}+\zeta_{1}\right)+\zeta_{2}\right)+\zeta_{3}\right)+\zeta_{3} \\
& \eta_{4}=\beta_{32} \beta_{32} \beta_{21} \beta_{21} \xi_{1}+\beta_{32} \beta_{32} \beta_{21} \zeta_{1}+\beta_{32} \beta_{32} \zeta_{2}+\beta_{32} \zeta_{3}+\zeta_{3} .
\end{aligned}
$$

All these analytical relationships were tested through the SEM. Both the relations among indicators and constructs as well as the causal relationships among latent variables. The first type of relationships is analysed to prove the consistency of the measurement or the construction of the unobservable variables, which is the first step to make sure that it is being measured "exactly" what it is pursued. That is the so-called measurement model. Additionally, the results achieved for the structural model, that is the one explaining the causality, will give the necessary information for the acceptance or rejection of the established hypotheses.

\section{Analysis and findings}

The measurement model results are summarised for all the latent variables handled along this paper in Table 5. One of the most useful measurements to check the internal consistency of the constructs is the composite reliability $\left(\rho_{c}\right)$, which, together with the Average Variance Extracted (AVE) and the Cronbach Alpha gives the idea of the goodness of the measurement model. According to the literature, all values can be considered into the acceptable thresholds (Fornell \& Larcker, 1981; Anderson \& Gerbing, 1988; Bagozzi \& Yi, 1988), as it is shown in Table 5.

Our model proves that there is a relationship between economy, health, quality of the job and work-life balance and well-being, nowadays. According to the assumptions, this relation will probably become stronger after COVID-19 crisis. With the Structural Equation Modelling (SEM), the results have shown that the economic situation is statistically significant for explaining the health situation and the health is statistically significant for explaining the strain in the job and the job quality. Finally, we demonstrated that the quality of the job is statistically significant for explaining the work-life balance as well as well-being. We made some insights about the role of social protection in the last part for this work but did not come to reliable conclusions.

\section{A. Previous step: details about the Job Quality Index}

All observable variables (the ones into the rectangle) are statistically significant for the construction of both (Job strain) and JQI. P-value is $<0.001$ for all of them. Results are shown in Figure 2. 
Table 5. Results for the measurement model for the latent (constructed) variables Job Strain Quality of Environment at Work, Work-life Balance, Wellbeing, Economy, Health (source: authors' calculation)

\begin{tabular}{|c|c|c|c|c|c|}
\hline Latent variables & Observable variables & $\lambda^{2}$ & lambda $(\lambda)$ & AVE & $\rho_{c}$ \\
\hline \multirow{3}{*}{$\begin{array}{l}\text { Job Strain Quality of } \\
\text { Environment at Work }\end{array}$} & Strain index 2005 & 0.856 & 0.925 & \multirow{3}{*}{0.850} & \multirow{3}{*}{0.860} \\
\hline & Strain index 2010 & 0.825 & 0.908 & & \\
\hline & Strain index 2015 & 0.869 & 0.932 & & \\
\hline \multirow{2}{*}{ Work-Life Balance } & No Working very long hours & 0.751 & 0.867 & \multirow{2}{*}{0.708} & \multirow{2}{*}{0.742} \\
\hline & Leisure \& care & 0.665 & 0.815 & & \\
\hline \multirow{4}{*}{ Wellbeing } & Water & 0.744 & 0.863 & \multirow{4}{*}{0.575} & \multirow{4}{*}{0.635} \\
\hline & Safety & 0.690 & 0.831 & & \\
\hline & Education score & 0.519 & 0.720 & & \\
\hline & Leisure \& care & 0.348 & 0.590 & & \\
\hline \multirow{3}{*}{ Economy } & Financial wealth & 0.543 & 0.737 & \multirow{3}{*}{0.793} & \multirow{3}{*}{0.810} \\
\hline & Disposable income & 0.871 & 0.933 & & \\
\hline & Personal earnings & 0.964 & 0.982 & & \\
\hline \multirow{3}{*}{ Health } & Life expectancy & 0.197 & 0.444 & \multirow{3}{*}{0.578} & \multirow{3}{*}{0.632} \\
\hline & Life satisfaction & 0.987 & 0.993 & & \\
\hline & Self-reported health & 0.549 & 0.741 & & \\
\hline
\end{tabular}

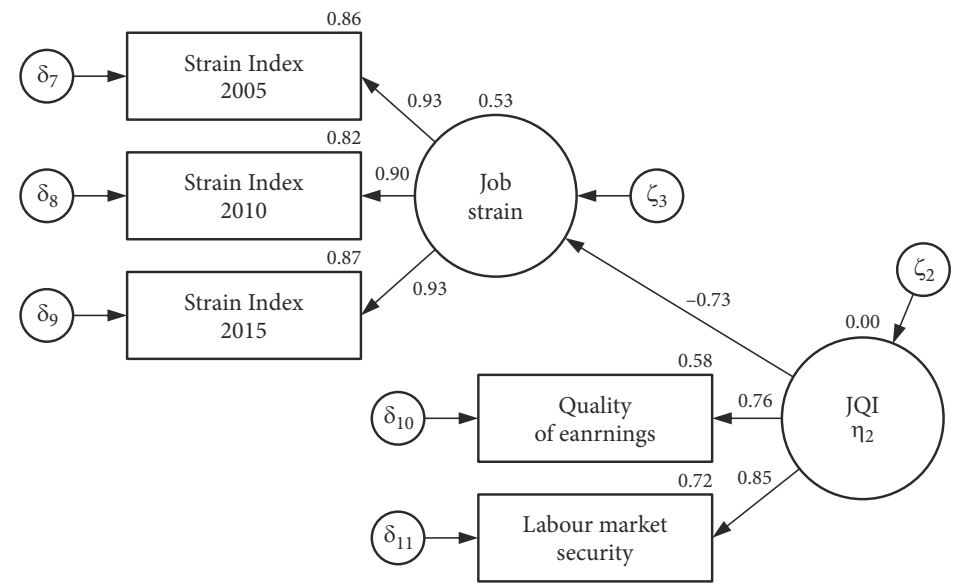

Figure 2. Job Quality Index. SEM analysis (source: authors' calculation)

\section{B. First approach: job strain and work-life balance (Model 1)}

This model gives quite good results in terms of expected relationships. The results of the calculus indicate that all coefficients are statistically significant, both for the construction of latent variables and for explaining the causal relationships among them. Additionally, all coefficients' signs are according to the expected values, according to the academic literature.

The results of the structural model for our first approach are according to previous works analysed in the literature. According to Figure 3, the calculus of the structural model indi- 


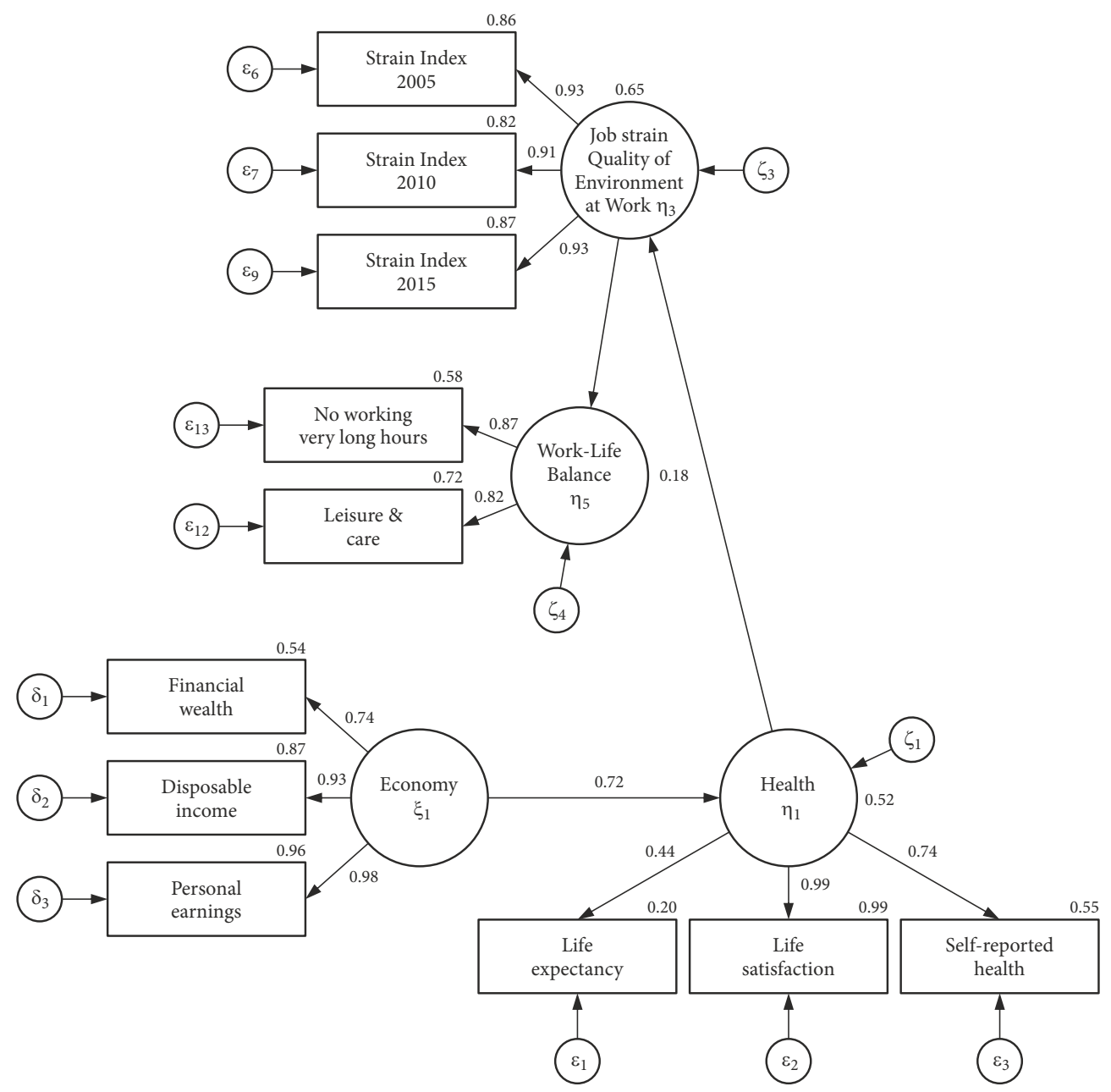

Figure 3. Model 1 - job strain and work-life balance (source: authors' calculation)

cates that the economy is relevant to explain health. It is significant ( $\mathrm{p}$-value $=0.022$ ), the health is statistically significant for explaining Job Strain ( $p$-value $=0.010$ ) and the job Strain is statistically significant for explaining Work-Life Balance ( $\mathrm{p}$-value $=0.329$. Moreover, all signs are in accordance to economic theory predictions.

Regression equations are:

Health $=0.72$ Economy $\left(\right.$ Fitted $\left.R^{2}=0.52\right)$;

Job Strain $=-0.82$ Health $\left(\right.$ Fitted $\left.R^{2}=0.65\right)$;

Work - Life Balance $=-0.42$ Job Strain $\left(\right.$ Fitted $\left.R^{2}=0.18\right)$.

\section{Second approach: job quality index and well-being (Model 2)}

To go beyond the strict space of work-life balance, we tried to extend the causal model for explaining personal well-being. A new model was carried out (Model 2 in Figure 4), widen- 
ing the concept and substituting the latent variable "work-life balance" by the "well-being" one. Then, we present a broader vision of the first model: including the Job Quality Index (instead of the Job Strain), and the well-being (instead of Work-life balance).

The essentials are the same, but it deals with a more complex scenario. Regarding the results, they are also quite reasonable in terms of regression analysis and confirm the previous
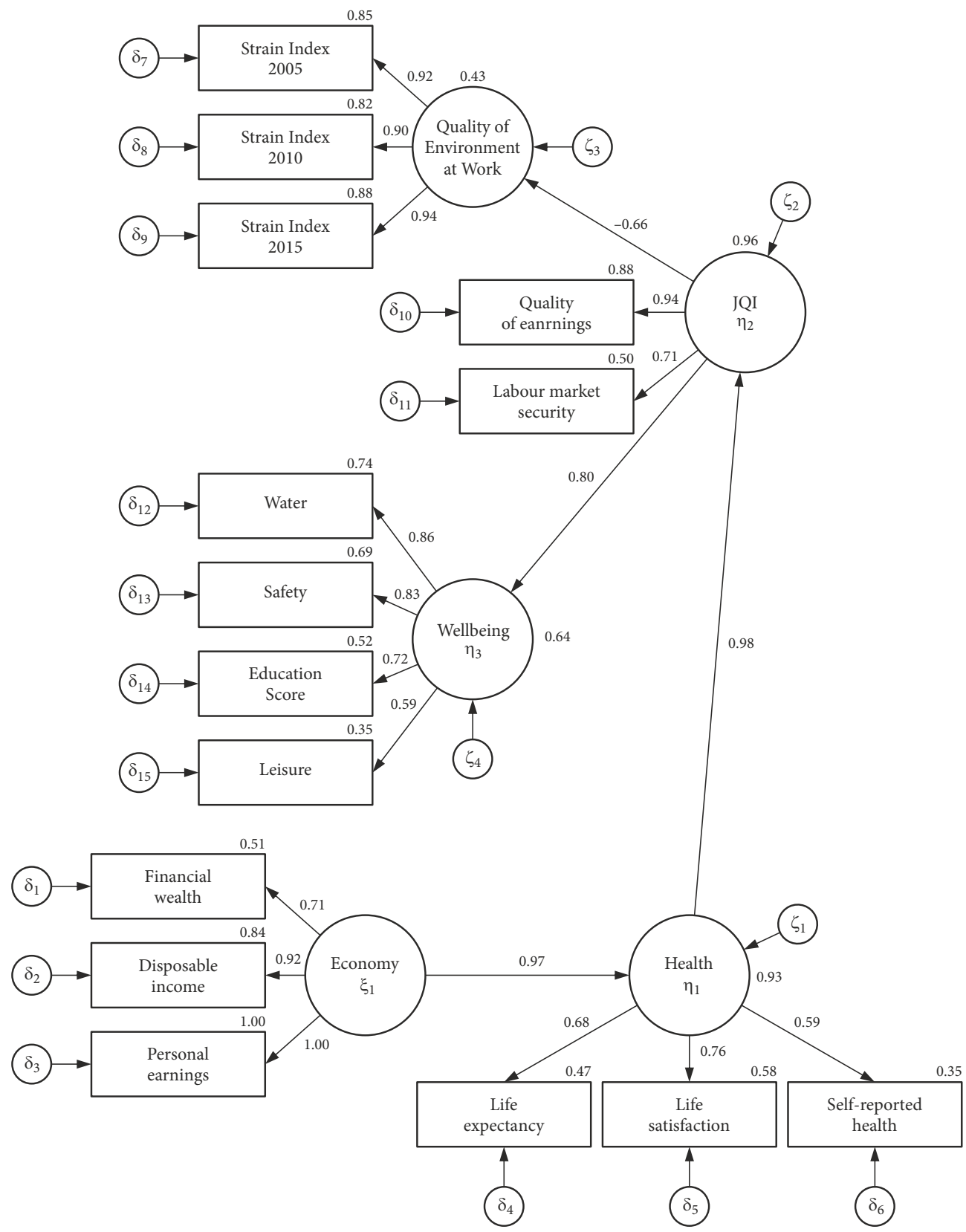

Figure 4. Model 2 - job quality index and well-being (source: authors' calculation) 
studies in this field (Novo-Corti et al., 2017). The economy is relevant to explain health, and it is significant ( $\mathrm{p}$-value $<0.001$ ). Additionally, health is statistically significant for explaining Job Quality Index ( $\mathrm{p}$-value $<0.001)$ and Job Quality is statistically significant for explaining Well-being (p-value $<0.001)$.

Regression equations are:

Health $=0.97$ Economy $\left(\right.$ Fitted $\left.R^{2}=0.93\right)$;

Job Quality Index $=0.98$ Health $\left(\right.$ Fitted $\left.R^{2}=0.96\right)$;

Wellbeing $=0.80 \mathrm{Job}$ Quality Index $\left(\right.$ Fitted $\left.R^{2}=0.64\right)$.

All the signs of the coefficients confirm the expected pattern, according to the theoretical model established following the academic literature. Besides, all of them are statistically significant. As a consequence, the results suggest that all null hypotheses should be rejected. These results confirm both that the initial and extended models (Model 1 and Model 2) behave according to the economic expected rules for the specific scenario of the developed countries, in basis to the empirical data used to tackle this SEM model for the OECD countries. See Table 6.

The results have shown that well-being is influenced by job quality and that it depends on job strain. Moreover, these variables depend on health status, and it depends on the economy. All these relationships point out to the importance of preserving the purchasing power of consumers, and the value of they earn, as well a good performance of labour market, together with the security and the quality of the job environment as an action to promote both work-family balance and global well-being. This state of affairs is a challenge for policymakers, particularly once that the pandemic scenario configures an uncertain future.

According to the United Nations Statistics Division (UNSD), COVID-19 pushing 40-60 million people from the world into extreme poverty.

The COVID-19 will probably cause the first increase in global poverty since the financial crisis from 2008. Global poverty, which means the share of the world's population living on less than $\$ 1.90$ per day, is projected to increase from $8.2 \%$ in 2019 to $8.6 \%$ in 2020 . IMF forecasts that economies will contract between $1-6 \%$ in 2020 , and the most remarkable consequences in terms of extreme poverty will be in low and middle-income countries. Thus, the economic impact of COVID-19 goes beyond the labour market, influencing not only jobs but also welfare and poverty.

Because of this, economic and social policies must aim at overcoming the COVID crisis by creating jobs and by supporting entrepreneurs and the business environment.

Table 6. Results of the tested hypothesis (source: authors' elaboration)

\begin{tabular}{|c|l|c|}
\hline Hypotheses & \multicolumn{1}{|c|}{ Statement } & Result \\
\hline H1 & Economic status does no influences health status & Rejected \\
\hline H2A & Health status does not influence job strain & Rejected \\
\hline H2B & Health status does not influence the quality of the job & Rejected \\
\hline H3 & The job strain does not influence the work-life balance & Rejected \\
\hline H4 & The quality of the job does not influence the well-being & Rejected \\
\hline
\end{tabular}




\section{Conclusions and discussions}

The job quality is a very important measure of the economies and of the relationship between economies and societies. We used this multi-dimensional concept to investigate the critical factors influencing the job strain and worker's quality of life. The COVID-19 pandemic has an unpredicted impact on the lifestyle of people, but also on employment, wages, health and workplace characteristics.

The results of this work are consistent with previous studies, both in the sphere related to general and individual wellbeing and in that of job strain, job quality or in aspects related to healthcare as well as to work-life balance. Likewise, they point in the same direction as the concerns shown by Europe 2020 Strategy, and international organizations as was indicated in the theoretical argumentation of this article. Additionally, by centring the analysis in light of the new situation generated by the pandemic, this work leads point to new implications that could be glimpsed.

The JQI includes the situation in the workplace in terms of security. Then, this information and its links to the job quality becomes crucial in times of pandemic, not only as an indicator but also as an explanatory variable. The value of this work is not only related to its explanatory capacity by establishing causal relations among labour market and workplace indicator with the health and well-being, in general terms but also because the security is one of the signs considered. It is well-known that a significant number of diseases and dead people were caused by the inappropriate working areas, unsafe clothing and scarcity or unavailability of the adequate protection devices at work, particularly for those working at the healthcare system or with oldest people. The well-being of citizens is affected through these channels, and the work-life balance is reshaped. Under these circumstances, using the structural equation model, we investigated the relationship between economy, health, quality of the job and work-life balance using the available data from OECD.

Since the economic status of people influences their health, the main conclusion would be that policymakers should improve the health system to influence the job strain more than social support. Due that data are previous to the COVID-19 crisis, the importance of health will increase in the future. So, by improving job quality and diminishing job strain, public policies could improve well-being.

The labour market is changing as a result of digitalisation and new technologies, as well as the increasing necessity of having security and safe places, free of contamination and creating a comfortable and self-perceived secure work environment. All these, together with the influence of teleworking on work-life balance are critical points for improving people lives and society. The impact of COVID-19 is an important factor, which affects people's work and lifestyle. The importance of online work, of work at home, which involves new skills, rules and regulations, is increasing. Because of this, education and health systems need to be reorganised to prepare the workforce for the new requirements.

The pandemic started disruptively, and now there is no going back. Knowing the interrelationships highlighted in this work could help policymakers design new policies to maximise well-being. According to the results of this paper, the recommendation of making more safe and secure working spaces should be a goal for public and private managers. 
Nevertheless, some limitations of his paper should be taken into account, mainly the temporary evolution of the tested relationships and their possible change during next post-COVID-19 period.

Variables causal relationships stated the link between economy, health and working conditions. Then, some different areas for policy actions become closely related. Namely, the job strain and job quality are influenced by health status, which will determine work-life balance as well as general well-being. Our analysis and results have proved the importance of economic-health-working spaces-family life-well-being interaction. Their interrelationships drive the focus to a mixed arena which could provide a fecund field for new research focused on how to conduct public policies and budgetary distribution from a holistic perspective.

\section{Author contribution}

All authors contributed equally to this paper.

\section{References}

Alsaywid, B., Housawi, A., Lytras, M., Halabi, H., Abuzenada, M., Alhaidar, S. A., \& Abuznadah, W. (2020). Residents' training in COVID-19 pandemic times: An integrated survey of educational process, institutional support, anxiety and depression by the Saudi Commission for Health Specialties (SCFHS). Sustainability, 12(24), 10530. https://doi.org/10.3390/su122410530

Anderson, J. C., \& Gerbing, D. W. (1988). Structural equation modelling in practice: A review and recommended two-step approach. Psychological Bulletin, 103(3), 411-423.

https://doi.org/10.1037/0033-2909.103.3.411

Autor, D. H. (2015). Why are there still so many jobs? The history and future of workplace automation. Journal of Economic Perspectives, 29(3). 3-30.

https://pubs.aeaweb.org/doi/pdfplus/10.1257/jep.29.3.3

Bagozzi, R. P., \& Yi, Y. (1988). On the evaluation of structural equation models. Journal of the Academy of Marketing Science, 16(1), 74-94. https://doi.org/10.1007/BF02723327

Beauregard, T. A., \& Henry, L. C. (2009). Making the link between work-life balance practices and organisational performance. Human Resource Management Review, 19(1), 9-22.

https://doi.org/10.1016/j.hrmr.2008.09.001

Biddle, C. J. (2020). Epidemics and pandemics as high consequence events: Expanding leadership challenges and responsibilities in business continuity during the COVID-19 pandemic and beyond. Journal of Business Continuity \& Emergency Planning, 14(1), 6-16. https://pubmed.ncbi.nlm.nih.gov/32847650/

Bliese, P. D., Edwards, J. R., \& Sonnentag, S. (2017). Stress and well-being at work: A century of empirical trends reflecting theoretical and societal influences, Journal of Applied Psychology, 102(3), 389-402. https://doi.org/10.1037/apl0000109

Bonsaksen, T., Thørrisen, M. M., Skogen, J. C., \& Aas, R. W. (2019). Who reported having a high-strain job, low-strain job, active job and passive job? The WIRUS Screening study. PLoS ONE, 14(12): e0227336. https://doi.org/10.1371/journal.pone.0227336

Cazes, S., Hijzen, A., \& Saint-Martin, A. (2015). Measuring and assessing job quality: The OECD job quality framework. OECD. https://www.oecd-ilibrary.org/docserver/5jrp02kjw1mr-en.pdf?expires= 1587504893\&id=id\&accname=guest\&checksum=9B9CD0DC123E1038543179C8E3353042 
Centra, M., \& Gualtieri, V. (2014). The quality of work during the employment crisis: The Italian case. International Review of Sociology, 24(2), 241-258. https://doi.org/10.1080/03906701.2014.933025

Chesbrough, H. (2020). To recover faster from Covid-19, open up: Managerial implications from an open innovation perspective. Industrial Marketing Management, 88, 410-413. https://doi.org/10.1016/j.indmarman.2020.04.010

Clark, A. E. (2005). Your money or your life: Changing job quality in OECD countries. British Journal of Industrial Relations, 43(3), 377-400. https://doi.org/10.1111/j.1467-8543.2005.00361.x

Davoine, L., Erhel, C., \& Guergoat-Lariviene, M. (2008). Monitoring quality in work: European employment strategy indicators and beyond. International Labour Review, 147(2-3), 163-198. https://doi.org/10.1111/j.1564-913X.2008.00030.x

de la Poza, E., Jodar, L., Merello, P., \& Todoli-Signes, A. (2020). Explaining the rising precariat in Spain. Technological and Economic Development of Economy, 26(1), 165-185. https://doi.org/10.3846/tede.2020.11332

Deci, E. L., Olafsen, A. H., \& Ryan, R. M. (2017). Self-determination theory in work organisations: The state of a science. Annual Review of Organizational Psychology and Organizational Behavior, 4, 19-43. https://doi.org/10.1146/annurev-orgpsych-032516-113108

Eberegbe, G., \& Giovanis, E. (2020). Exploring the impact of job satisfaction domains on firm performance: Evidence from Great Britain. Journal of Applied Economics and Business Research, 10(2), 96-114. https://mpra.ub.uni-muenchen.de/104046/

Elci, E., \& Uzunboylu, H. (2020). The development of a universal and cultural values scale for values education. South African Journal of Education, 40(Suppl 1), 1850. http://www.sajournalofeducation.co.za/index.php/saje/article/view/1850/955

Erhel, C., \& Guergoat-Larivière, M. (2016). Innovation and job quality regimes: A joint typology for the EU (QuInnE Working Paper WP, 5-2-2016). QuInnE. http://tools.quinne.eu/static/quant_app/WP5_2_25112016_final.pdf

European Commission. (2010). Europe 2020. A strategy for smart, sustainable and inclusive growth. 3.3.2010, COM/2010/2020 final. European Commission, Brussels.

Findlay, P., Warhurst, C., Keep, E., \& Lloyd, C. (2017). Opportunity knocks? The possibilities and levers for improving job quality. Work and Occupations, 44(1), 3-22. https://doi.org/10.1177/0730888416689813

Fornell, C., \& Larcker, D. F. (1981). Evaluating structural equation models with unobservable variables and measurement error. Journal of Marketing Research, 18(1), 39-50. https://doi.org/10.2307/3151312

Gentilini, U., Almenfi, M., \& Orton, I. (2020). Social protection and jobs responses to COVID-19: A realtime review of country measures (A "living paper", version 1, March 20, 2020). World Bank. Social Protection and Jobs Global Practice. http://www.ugogentilini.net/wp-content/uploads/2020/03/ global-review-of-social-protection-responses-to-COVID-19-2.pdf

Goods, C., Veen, A., \& Barrat, T. (2019). “Is your gig any good?” Analysing job quality in the Australian platform-based food-delivery sector. Journal of Industrial Relations, 61(4), 502-527. https://doi.org/10.1177/0022185618817069

Green, F. (2006). Demanding work: The paradox of job quality in the affluent economy. Princeton University Press. https://doi.org/10.1515/9781400849437

Greenhaus, J. H., Collins, K. M., \& Shaw, J. D. (2003). The relation between work-family balance and quality of life. Journal of Vocational Behavior, 63(3), 510-513. https://doi.org/10.1016/S0001-8791(02)00042-8

Hall, R. (2006). Temporary agency work and HRM in Australia: "Cooperation, specialisation and satisfaction for the good of all"? Personnel Review, 35(2), 158-174.

https://doi.org/10.1108/00483480610645803 
Hauff, S., \& Kirchner, S. (2014). Cross-national differences and trends in job quality: A literature review and research agenda (Discussion paper No. 13, January 2013). University of Hamburg. https://inclusivegrowth.be/downloads/tna-activity-reports/c01-23-working-paper.pdf

Hessels, J., Rietveld, C. A., \& van der Zwan, P. (2017). Self-employment and work-related stress: The mediating role of job control and job demand. Journal of Business Venturing, 32(2), 178-196. https://doi.org/10.1016/j.jbusvent.2016.10.007

Hijzen, A., \& Menyhert, B. (2016). Measuring labour market security and its implications for individual well-being (OECD social, employment and migration Working Papers, No. 175). OECD Publishing. https://ideas.repec.org/p/oec/elsaab/175-en.html

Inanc, H. (2018). Unemployment, temporary work, and subjective well-being: The gendered effect of spousal labor market insecurity. American Sociological Review, 83(3), 536-566. https://doi.org/10.1177/0003122418772061

Inanc, H., Zhou, Y., Gallie, D., Felstead, A., \& Green, F. (2015). Direct participation and employee learning at work. Work and Occupations, 42(4), 447-475. https://doi.org/10.1177/0730888415580650

International Labour Organization. (2013). Decent work indicators: Guidelines for producers and users of statistical and legal framework indicators. (ILO Manual $2^{\text {nd }}$ version). Geneva. https://www.ilo. org/wcmsp5/groups/public/---dgreports/---integration/documents/publication/wcms_229374.pdf

International Labour Organization. (2020, March 18). COVID-19 and the world of work: Impact and policy responses. (ILO Monitor $1^{\text {st }}$ ed.). Geneva. https://www.ilo.org/wcmsp5/groups/public/--dgreports/---dcomm/documents/briefingnote/wcms_738753.pdf

Jöreskog, K. G. (1973). A general method for estimating a linear structural equation system. In A. S. Goldberger \& O. D. Duncan (Eds.), Structural equation mode/s in the social sciences (pp. 85-112). Seminar Prcss.

Jöreskog, K. G., \& Sörbom, D. (1982). Recent developments in structural equation modeling. Journal of Marketing Research, 19(4), 404-416. https://doi.org/10.1177/002224378201900402

Jurevičienè, D., Skvarciany, V., \& Lagunavičiūtè, A. (2020). Factors influencing individuals' decisionmaking and causing financial crisis. Journal of Business Economics and Management, 21(4), 11491164. https://doi.org/10.3846/jbem.2020.12890

Kalleberg, A. (2011). Good jobs, bad jobs: The rise of polarised and precarious employment systems in the United States, 1970s to 2000s. New York: Russell Sage Foundation. https://arnekalleberg.web.unc.edu/books/good-jobs-bad-jobs/

Kelliher, C., Richardson, J., \& Boiarintseva, G. (2019). All of work? All of life? Reconceptualising worklife balance for the 21st century. Human Resource Management Journal, 29(2), 97-112. https://doi.org/10.1111/1748-8583.12215

Luecke, C., \& Knabe, A. (2020). How much does others' protection matter? Employment protection, future labour market prospects and well-being. Oxford Economic Papers, 72(3), 893-914. https://doi.org/10.1093/oep/gpz050

Moen, P., Kelly, E., Fan, W., Lee, S. R., Alemira, D., Kossek, E. E., \& Buxton, O. M. (2016). Does a flexibility/support organisational initiative improve high-tech employees' well-being? Evidence from the work, family, and health network. American Sociological Review, 81(1), 134-164. https://doi.org/10.1177/0003122415622391

Muñoz de Bustillo, R., Fernandez-Macias, E., Anton, J.-I., \& Esteve, F. (2011). Measuring more than money: The social economics of job quality. Edward Elgar Publishing. https://doi.org/10.4337/9781849805919

Novo-Corti, I., López-Arranz, A., González-Laxe, F., \& Picatoste, J. (2017). Well-being at work: Self perception of workers from a gender perspective. Economic Computation \& Economic Cybernetics Studies \& Research, 51(3), 161-177. https://ideas.repec.org/a/cys/ecocyb/v50y2017i3p161-177.html

OECD. (2013). How's life? 2013: Measuring well-being. https://doi.org/10.1787/9789264201392-en 
OECD. (2014). OECD Employment Outlook. OECD. https://read.oecd-ilibrary.org/employment/oecdemployment-outlook-2014_empl_outlook-2014-en\#page251

OECD. (2016). How good is your job? Measuring and assessing job quality. OECD. https://www.oecd.org/statistics/job-quality.htm

OECD. (2020a). OECD employment Outlook 2020: Worker security and the COVID-19 crisis. OECD Publishing. https://doi.org/10.1787/1686c758-en

OECD. (2020b). OECD.Stat. Statistics - Official statistics of OECD. https://stats.oecd.org/index.aspx?queryid=82335

Osterman, P., \& Shulman, B. (2011). Good jobs in America: Making work better for everyone. Russell Sage Foundation. https://www.jstor.org/stable/43550113?seq=1

Ozturk, M., DurdYev, S., Aras, O. N., Ismail, S., \& Banaitienė, N. (2019). How effective are labor wages on labor productivity?: An empirical investigation on the construction industry of New Zealand. Technological and Economic Development of Economy, 26(1), 258-270. https://doi.org/10.3846/tede.2020.11917

Rusli, B. N., Edimansyah, B. A., \& Naing, L. (2008). Working conditions, self-perceived stress, anxiety, depression and quality of life: A structural equation modelling approach. BMC Public Health, 8(1), 48. https://doi.org/10.1186/1471-2458-8-48

Saladino, V., Algeri, D., \& Auriemma, V. (2020). The psychological and social impact of COVID-19: New perspectives of well-being. Frontiers in Psychology, 11, 577684. https://doi.org/10.3389/fpsyg.2020.577684

Schmitt, A., Den Hartog, D. N., \& Belschak, F. D. (2016). Transformational leadership and proactive work behaviour: A moderated mediation model including work engagement and job strain. Journal of Occupational and Organizational Psychology, 89(3), 588-610. https://doi.org/10.1111/joop.12143

Sicilia M. A., \& Lytras, M. (2005). Scenario-oriented reusable learning object characterisations. International Journal of Knowledge and Learning, 1(4), 332-341. https://doi.org/10.1504/IJKL.2005.008355

Simion, C. J., \& Warner, J. T. (1992). Matchmaker, matchmaker - The effect of old boy networks on job match quality, earnings, and tenure. Journal of Labor Economics, 10(3), 306-330. https://doi.org/10.1086/298289

Spruit, M., \& Lytras, M. (2018). Applied data science in patient-centric healthcare. Telematics and Informatics, 35(4), 643-653. https://doi.org/10.1016/j.tele.2018.04.002

Twerge, J. M. (2010). A review of the empirical evidence on generational differences in work attitudes. Journal of Business and Psychology, 25(2), 201-210. https://doi.org/10.1007/s10869-010-9165-6

UNICEF, ILO, UN Women. (2020). Family-friendly policies and other good workplace practices in the context of Covid-19: Key steps employers can take. https://www.unicef.org/media/66351/file/Familyfriendly-policies-covid-19-guidance-2020.pdf

United Nations. (2015). Handbook of measuring quality of employment: A statistical framework. New York and Geneva. http://www.unece.org/fileadmin/DAM/stats/publications/2015/ECE_CES_40.pdf

United Nations Statistics Division. (2020). How Covid-19 is changing the world: A statistical perspective. Committee for the Coordination of Statistical Activities. https://unstats.un.org/unsd/ccsa/documents/covid19-report-ccsa.pdf

Vander Elst, T., De Cuyper, N., Baillien, E., Niesen, W., \& De Witte, H. (2016). Perceived control and psychological contract breach as explanations of the relationships between job insecurity, job strain and coping reactions: Towards a theoretical integration. Stress and Health, 32(2), 100-116. https://doi.org/10.1002/smi.2584

Vargas-Vera, M., \& Lytras, M. (2008). Exploiting semantic web and ontologies for personalised learning services: Towards semantic web-enabled learning portals for real learning experiences. International Journal of Knowledge and Learning, 4(1), 1-17. https://doi.org/10.1504/IJKL.2008.019734 
Warhurst C., Wright S., \& Lyonette, C. (2017). Understanding and measuring job quality (Research report Part 1 - Thematic Literature Review). Warwick Institute for Employment Research. Warwick, Poland. https://www.cipd.co.uk/Images/understanding-and-measuring-job-quality-3_tcm18-33193.pdf

Warren, T., \& Lyonette, C. (2018). Good, bad and very bad part-time jobs for women? Re-examining the importance of occupational class for job quality since the "Great Recession" in Britain. Work, Employment and Society, 32(4), 747-767. https://doi.org/10.1177/0950017018762289

Wright, S. (1934). The method of path coefficients. Annals of Mathematical Statistics, 5(3), 161-215. https://doi.org/10.1214/aoms/1177732676

Wright, S. (1960). Path coefficients and path regressions: Alternative or complementary concepts? Biometrics, 16(2), 189-202. https://doi.org/10.2307/2527551

Zhou, K. Z., Li, J. J., Zhou, N., \& Su, C. T. (2008). Market orientation, job satisfaction, product quality, and firm performance: Evidence from China. Strategic Management Journal, 29(9), 985-1000. https://doi.org/10.1002/smj.700

Zikic, J., \& Klehe, U. C. (2006). Job loss as a blessing in disguise: The role of career exploration and career planning in predicting reemployment quality. Journal of Vocational Behavior, 69(3), 391-409. https://doi.org/10.1016/j.jvb.2006.05.007 